\title{
Peran Dinas Lingkungan Hidup Kota Jambi dalam Penerapan Sanksi Administrasi Denda Berdasarkan Peraturan Daerah Nomor 8 Tahun 2013 Tentang Pengelolaan Sampah
}

\author{
Herma Yanti $^{1 *}$, Dedy Syaputra ${ }^{2}$, Melly Susyandari ${ }^{3}$ \\ ${ }^{1,2,3}$ Fakultas Hukum Universitas Batanghari \\ Jalan Slamet Riyadi Broni Kota Jambi, Telp: (0741) 65351 \\ *Correspondence email: hermayanti67@gmail.com; jambidedy05@gmail.com; mellysusyandari19@gmail.com
}

\begin{abstract}
Abstrak. Berdasarkan Peraturan Daerah Kota Jambi Nomor 8 Tahun 2013 tentang Pengelolaan Sampah, pelanggaran atas larangan pembuangan sampah dikenakan sanksi administrasi denda sebagai sanksi utamanya. Besaran dendanya ditetapkan dengan jumlah yang tinggi dan penerapannya oleh Dinas Lingkungan Hidup (DLH) Kota Jambi. Meski demikian, pelanggaran terhadap larangan tersebut masih banyak dilakukan. Penelitian ini bertujuan membahas bagaimana pengaturan besaran denda tersebut dan bagaimana peran DLH Kota Jambi dalam penerapan sanksi denda terhadap pelanggaran yang terjadi. Pendekatan yang digunakan yaitu pendekatan hukum sosiologis, dan data-data penelitian terdiri dari dari data primer dan data sekunder. Peran DLH diukur dari kemampuan DLH dalam menerapkan besaran denda yang ditetapkan, dari jumlah dan rentang waktu penerapan denda serta dari jenis tindakan pelanggaran yang telah diterapkan denda. Dari hasil penelitian diketahui bahwa dilihat dari kemampuan menerapkan besaran denda, peran DLH belum optimal karena besaran denda yang diterapkan terhadap pelanggar belum semuanya sesuai ketentuan yang ditetapkan. Dari jumlah dan rentang waktu penerapan denda juga belum optimal karena belum sebanding dengan intensitas pelanggaran yang dapat dilihat setiap hari sedangkan penerapan denda yang dilakukan tidak selalu ada setiap bulannya. Dari jenis tindakan pelanggaran yang telah dikenakan denda juga belum optimal karena belum semua jenis pelanggaran yang terjadi dapat dilihat penerapan sanksi dendanya.
\end{abstract}

Kata Kuci: Peran; larangan; sanksi administrasi denda

Abstract. Based on the Jambi City Regional Regulation Number 8 of 2013 concerning Waste Management, violations of the prohibition on waste disposal are subject to administrative sanctions as the main penalty. The amount of the fine is set at a high amount and is applied by the Jambi City Environment Agency (DLH). However, there are still many violations of the prohibition. This study aims to discuss how to regulate the amount of the fine and how the role of DLH Jambi City in implementing fines for violations that occur. The approach used is the sociological legal approach, and research data consists of primary data and secondary data. The role of DLH is measured by the ability of DLH to apply the amount of fines that have been determined, from the amount and time span of the application of fines and from the types of violations for which fines have been applied. From the research results, it is known that from the ability to apply the amount of fines, the role of DLH is not optimal because the amount of fines applied to violators is not all according to the stipulated provisions. The amount and time span of the application of fines are also not optimal because they are not yet comparable to the intensity of violations that can be seen every day, while the application of fines that are carried out does not always exist every month. From the types of violations that have been subject to fines are also not optimal because not all types of violations that have occurred can be seen the application of the fine sanctions.

Keywords: Role; prohibition; administrative sanctions fines

\section{PENDAHULUAN}

Penyelenggaraan pemerintahan dalam negara hukum demokratis memberikan ruang bagi pemerintah untuk melakukan pengendalian melalui penerapan sanksi administrasi terhadap tindakan atau perbuatan yang melanggar norma-norma hukum administrasi. Hal ini penting dilakukan pemerintah agar norma-norma pemerintahan yang telah ditetapkan dapat berjalan sebagaimana mestinya. Berbeda dengan sanksi lainnya, sanksi administrasi ini diterapkan oleh pemerintah secara langsung terhadap pelanggar tanpa melalui proses pengadilan.

Penerapan sanksi administrasi ini memberikan jalan bagi pemerintah untuk melakukan suatu tindakan yang dapat mengarahkan perilaku warga masyarakat sesuai dengan norma pemerintahan yang ada.

Penerapan sanksi administrasi ini merupakan penerapan kewenangan pemerintah yang telah ditentukan dalam peraturan perundang-undangan untuk menegakkan norma-norma yang tertuang dalam hukum administrasi. Penegakan hukum pemerintahan ini dimaksudkan untuk meneguhkan norma-norma hukum pemerintahan sehingga terwujud ketertiban dalam kehidupan masyarakat. Hal ini diharapkan agar tujuan penyelenggaraan pemerintahan yang ingin diwujudkan dapat tercapai.

Penegakan hukum administrasi tersebut diterapkan dalam hal terjadinya pelanggaran hukum oleh warga masyarakat terhadap norma-norma hukum administrasi, seperti melanggar larangan-larangan yang telah ditetapkan dalam norma hukum administrasi, sehingga tujuan ditetapkannya aturan tersebut tidak terwujud. Untuk itu, penegakan hukum harus dilakukan oleh pemerintah agar pelanggaran terhadap norma hukum yang telah ditetapkan dapat segera 
dihentikan. Aminudin Ilmar menegaskan bahwa "sekecil apapun pelanggaran yang dilakukan warga masyarakat harus segera dilakukan tindakan penegakan hukum pemerintahan agar norma-norma hukum pemerintahan dapat ditaati dengan baik oleh warga masyarakat."1

Salah satu sanksi administrasi tersebut yaitu berupa denda yang tertuang dalam Peraturan Daerah Kota Jambi (Perda) Nomor 8 Tahun 2013 tentang Pengelolaan Sampah. Pengaturan ini bertujuan untuk mewujudkan lingkungan hidup yang sehat, bersih, rapi dan indah secara berkelanjutan, sementara di sisi lain pertumbuhan kota dan pertambahan penduduk yang tinggi serta pola konsumsi masyarakat berakibat pada timbulnya permasalahan meningkatnya produksi sampah.

Guna mengatasi permasalahan tersebut, Perda ini menetapkan 13 jenis larangan terkait dengan pembuangan sampah sebagaimana tertuang dalam Pasal 47 yang melarang setiap orang/badan :

1. Memasukkan sampah ke daerah;

2. Melakukan kegiatan impor sampah;

3. Mencampur sampah dengan limbah berbahaya;

4. Membuang, menumpuk, menyimpan sampah atau bangkai binatang di jalan, jalur hijau, taman, sungai, fasilitas umum dan tempat lainnya yang sejenis;

5. Membuang sampah dan/atau kotoran lainnya dari atas kendaraan;

6. Membuang sampah ke TPS dengan menggunakan kendaraan bermotor yang volumenya lebih dari 1 (satu) kubik;

7. Membakar sampah dan/atau kotoran lainnya di jalan, jalur hijau, taman, sungai, saluran drainase dan tempattempat umum lainnya;

8. Membuang air besar (hajar besar) di jalan, jalur hijau, taman, sungai, saluran drainase dan tempat umum;

9. Mengeruk atau mengais sampah di TPS, kecuali oleh petugas untuk kepentingan dinas;

10.Membuang sampah di luar tempat/lokasi pembuangan yang telah ditetapkan;

11.Membuang sampah di TPS di luar waktu yang telah ditentukan;

12.Membuang sampah di TPS klinis dan limbah B3 lainnya ke TPS dan TPA;

13.Mengelola sampah yang menyebabkan pencemaran dan/atau perusakan lingkungan.

Pelanggaran terhadap larangan-larangan tersebut diancam dengan sanksi administrasi berupa denda sebagaimana tertuang dalam Pasal 56 ayat (1). Besaran denda tersebut berdasarkan Peraturan Walikota Nomor 84 Tahun 2018 tentang Tatacara Penerapan Sanksi Administratif Peraturan Daerah Kota Jambi Nomor 8 Tahun 2013 tentang Pengelolaan Sampah, ditetapkan dengan jumlah nominal relatif tinggi sebesar paling banyak Rp.40.000.000,(empat puluh juta rupiah) dan penerapannya dilaksanakan oleh DLH Kota Jambi.

Banyaknya larangan dan besarnya jumlah denda yang ditentukan, mengindikasikan besarnya peran yang diberikan kepada DLH Kota Jambi untuk menegakkan ketentuan tersebut melalui penerapan sanksi administrasi denda yang tinggi terhadap pelanggarnya. Karena itu DLH Kota Jambi diharapkan dapat mengimplementasikan penerapan sanksi administrasi denda yang telah ditentukan, sekaligus mewujudkan kepatuhan masyarakat terhadap ketentuan yang telah ditetapkan. Sebab menurut Philipus M. Hadjon "tidak ada gunanya memasukkan kewajiban dan larangan terhadap warga masyarakat di dalam peraturan perundang-undangan, manakala aturan tingkah laku tersebut tidak dapat dipaksakan keberlakuannya oleh pemerintah". ${ }^{2}$

Melalui penerapan sanksi administrasi denda tersebut diharapkan berbagai larangan yang telah ditetapkan dapat dipatuhi oleh masyarakat. Namun berdasarkan observasi peneliti di lapangan, menunjukkan masih banyaknya pelanggaran-pelanggaran yang dilakukan masyarakat terhadap berbagai larangan yang telah ditentukan. Hal ini mengindikasikan bahwa penerapan sanksi administrasi denda terhadap pelanggaran tersebut belum berjalan sebagaimana mestinya.

\section{METODE}

\section{Pendekatan Penelitian.}

Penelitian ini merupakan penelitian hukum empiris, yaitu penelitian hukum yang mengkaji serta menganalisis bekerjanya hukum di dalam masyarakat. ${ }^{3}$ Untuk itu penelitian ini dilakukan dengan menggunakan pendekatan yuridis sosiologis, dalam arti pendekatan terhadap hukum sebagai suatu norma dan pendekatan terhadap masyarakat dengan melihat realita di dalam masyarakat. ${ }^{4}$ Dalam hal ini yaitu dengan menelaah Perda Nomor 8 Tahun 2013 terkait ketentuan tentang larangan pembuangan sampah dan ancaman sanksi administrasi denda bagi pelanggarnya, kemudian

\footnotetext{
${ }^{1}$ Aminuddin Ilmar, Hukum Tata Pemerintahan, (Jakarta : Prenada Media Group, 2014), hlm. 293.

${ }^{2}$ Philipus M. Hadjon, et.al. Pengantar Hukum Administrasi Indonesia, (Yogyakarta : Gajah Mada University Press, 1993) hlm.245.

3 Lihat dalam Ishaq, Metode Penelitian Hukum, (Bandung : Alfabeta, 2016), hlm. 71

${ }^{4}$ Lihat Suratman dan Phillip Dillah, Metode Penelitian Hukum, (Bandung : Alfabeta, 2012), hlm. 229
} 
menelaah penerapan sanksi administrasi denda yang telah diterapkan atas pelanggaran larangan pembuangan sampah tersebut oleh DLH Kota Jambi sesuai dengan wewenang yang diberikan kepadanya.

\section{Ruang Lingkup atau Objek Penelitian}

Salah satu objek kajian dalam penelitian hukum empiris adalah peranan lembaga atau institusi dalam penegakan hukum. $^{5}$ Hal tersebut relevan dengan objek kajian dalam penelitian yaitu mengkaji peran DLH dalam penerapan sanksi administrasi denda terhadap pelanggaran larangan pembuangan sampah berdasarkan Perda Nomor 8 Tahun 2013. Objek penelitian meliputi kajian terhadap peran DLH dalam menerapkan besaran denda sesuai besaran denda yang ditetapkan dalam pedoman penerapan sanksi yang ditentukan sebelumnya dengan jumlah yang tinggi. Kemudian kajian terhadap jumlah dan rentang waktu penerapan sanksi yang telah dilakukan, hal ini mengingat banyaknya tindakan pelanggaran yang terlihat di lapangan. Selanjutnya mengingat banyaknya jenis larangan yang telah ditetapkan dalam Perda, maka dilakukan juga kajian terhadap peran DLH dalam menerapkan sanksi administrasi denda berdasarkan jenis pelanggaran yang terlihat di lapangan.

\section{Bahan dan Alat Utama}

Dalam penelitian hukum empiris, bahan atau data yang diperlukan adalah data primer dan data sekunder. Data primer yakni data yang diperoleh sumbernya langsung dari lapangan. ${ }^{6}$ Dalam penelitian ini data primer berupa datadata tentang penerapan sanksi administrasi denda yang telah dilakukan DLH Kota Jambi. Data tersebut diperoleh secara langsung dari responden pada DLH Kota Jambi yang terkait dengan penerapan sanksi administrasi denda. Kemudian juga data-data yang terkait dengan tindakan pelanggaran atas larangan pembuangan sampah yang diperoleh dengan melakukan pengamatan secara langsung ke beberapa tempat pembuangan sampah yang ada di lapangan. Sedangkan data sekunder diperoleh dari penelitian kepustakaan, terdiri dari peraturan perundang-undangan terkait dengan penerapan sanksi administrasi denda, buku-buku, jurnal serta referensi terkait lainnya.

Adapun alat utama yang dipergunakan untuk mengumpulkan data-data penelitian berupa alat tulis untuk mencatat segala hal yang berkaitan dengan data yang diperoleh dari penelitian yang lakukan dan juga camera Handpond untuk mendokumentasikan data tentang tindakan pelanggaran terhadap larangan pembuangan sampah yang ditemukan di lapangan.

\section{Tempat/Lokasi Penelitian}

Penelitian ini dilakukan pada DLH Kota Jambi serta di beberapa tempat pembuangan sampah yang di Kota Jambi.

\section{Teknik Pengumpulan Data}

Untuk pengumpulan data dilakukan dengan teknik sebagai berikut:

1. Untuk pengumpulan data primer dilakukan dengan cara wawancara dan observasi. Wawancara dilakukan secara langsung dengan responden pada DLH Kota Jambi yang terkait dalam penerapan sanksi administrasi denda yaitu pegawai Bidang Penegakan Hukum, Kepala Bidang Pengendalian dan Pengawasan Persampahan serta pegawai Bidang Yustisi DLH Kota Jambi. Sedangkan observasi dilakukan dengan melihat secara langsung ke beberapa tempat pembuangan sampah yang ada di lapangan untuk mengetahui tindakan-tindakan maupun bukti pelanggaran terhadap larangan pembuangan sampah yang dilakukan.

2. Untuk pengumpulan data sekunder dilakukan dengan cara mempelajari peraturan perundang-undangan, hasil penelitian, maupun referensi lain yang terkait dengan masalah penelitian.

\section{Defenisi Operasional Variabel Penelitian}

Merumuskan defenisi operasional variabel penelitian sangat penting untuk memberikan batasan sekaligus petunjuk dalam penelitian agar langkah yang dilakukan tetap fokus. ${ }^{7}$ Dalam penelitian ini rumusan dari variabel penelitian sebagai berikut:

1. Peran, menurut Ralph Linton adalah "the dynamic aspect of a status (aspek dinamis dari status). Suatu status adalah " $a$ collection of rights and duties" (suatu kumpulan hak dan kewajiban). Seseorang menjalankan peran manakala ia menjalankan hak dan kewajiban yang merupakan statusnya. Rumusan tersebut sama dengan rumusan peranan menurut Soerjono Soekant, peranan (role) adalah aspek yang dinamis dari kedudukan (status). Apabila seseorang melaksanakan hak-hak dan kewajiban sesuai dengan kedudukannya, maka dia menjalankan suatu

\footnotetext{
${ }^{5}$ Ishaq, Op.Cit, hlm. 70

6 Ibid, hal. 71

${ }^{7}$ Lihat Mukti Fajar dan Yulianto Achmad, Dualisme Penelitian Hukum Normatif dan Empiris, (Yogyakarta : Pustaka
} Pelajar, 2019), hlm. 74 
peranan. Berdasarkan uraian di atas, peran akan kelihatan apabila seseorang atau badan melaksanakan hak-hak dan kewajiban dalam kedudukan tertentu yang dipunyainya. Dengan kata lain peran itu lebih menunjukkan pada fungsi yang dilaksanakan. ${ }^{8}$

2. Dinas Lingkungan Hidup Kota Jambi berdasarkan Perda Kota Jambi Nomor 14 Tahun 2016 tentang Pembentukan dan Susunan Perangkat Daerah, merupakan perangkat daerah yang mempunyai tugas membantu Walikota dalam menyelenggarakan urusan pemerintahan bidang lingkungan hidup.

3. Penerapan, dalam hal ini menurut Kamus Besar Bahasa Indonesia penerapan berarti pengenaan. ${ }^{9}$

4. Sanksi Administrasi. Menurut Peraturan Walikota Jambi Nomor 84 Tahun 2018 sanksi administrasi adalah tindakan oleh badan/pejabat pemerintahan secara langsung terhadap pelanggaran peraturan daerah.

5. Denda merupakan salah satu jenis dari sanksi administrasi yang diterapkan oleh pemerintah secara langsung terhadap pelanggaran hukum administrasi. Dalam berbagai literature hukum administrasi, istilah denda ini biasa disebut dengan istilah denda administratif, termasuk dalam Peraturan Walikota Jambi Nomor 84 Tahun 2018, yang dalam hal ini didefenisikan sebagai denda yang dikenakan atas pelanggaran peraturan perundang-undangan di bidang persampahan.

\section{Teknik Analisis Data}

Data-data penelitian yang telah dikumpulkan disusun dan disajikan secara sistimatis, selanjutnya dianalisis. Dalam penelitian hukum empiris dilakukan analisis secara secara deskriptif kualitatif, yaitu dengan memberikan pemaparan dan menjelaskan secara rinci dan mendalam untuk mengungkap apa yang terdapat dibalik dari peristiwa nyata dengan maksud mencari nilai-nilai yang terkandung di dalamnya. ${ }^{10}$ Dalam penelitian ini peneliti memaparkan dan menguraikan secara rinci dan mendalalam tentang penerapan sanksi administrasi denda yang dilakukan DLH Kota Jambi terhadap pelanggaran atas larangan pembuangan sampah yang telah ditentukan berdasarkan Perda Nomor 8 Tahun 2013. Dari pemaparan tersebut kemudian diambil kesimpulan yang menggambarkan peran DLH dalam penerapan sanksi administrasi denda berdasarkan tolok ukur yang digunakan.

Peran DLH dalam penerapan sanksi administrasi denda tersebut diukur dari kemampuan DLH dalam menerapkan besaran denda sebagaimana ditentukan dalam pedoman penerapan sanksi administrasi besaran denda yang yang telah ditetapkan sebelumnya. Peran DLH dapat dikatakan optimal, apabila besaran sanksi administrasi denda yang telah diterapkan tersebut semuanya sesuai dengan jumlah yang ditentukan dalam pedoman.

Kemudian dilihat juga dari jumlah dan rentang waktu penerapan sanksi denda yang telah dilakukan oleh DLH. Hal ini mengingat intensitas pelanggaran yang dapat terlihat di lapangan setiap hari, maka apabila penerapan sanksi denda yang telah dilakukan DLH juga telah terlihat minimal satu kali saja setiap bulannya, maka peran DLH dalam penerapan sanksi administrasi denda dapat dikatakan telah optimal.

Selanjutnya juga dilihat dari jenis tindakan pelanggaran yang telah dikenakan sanksi administrasi denda. Hal ini mengingat banyaknya jenis larangan yang diatur dalam Perda Nomor 8 Tahun 2013. Dalam hal ini peran DLH dapat dikatakan telah optimal apabila semua jenis tindakan pelanggaran yang terlihat di lapangan, juga telah terlihat adanya penerapan sanksi administrasi denda yang telah dijatuhkan DLH terhadap jenis pelanggaran tersebut.

\section{HASIL DAN PEMBAHASAN}

\section{Pengaturan sanksi denda administratif Atas Pelanggaran Larangan Perda Nomor 8 Tahun 2013 tentang Pengelolaan Sampah}

Sanksi administrasi denda merupakan salah satu jenis sanksi administrasi yang diterapkan secara langsung oleh pemerintah tanpa melalui pengadilan sebagai reaksi atas pelanggaran dengan tujuan menghukum pelanggar agar tidak mengulangi kembali pelanggaran yang dilakukan. Berbeda dengan sanksi pidana, sanksi administrasi ini dilaksanakan pemerintah secara langsung terhadap pelanggar tanpa melalui pengadilan meskipun tujuannya sama yaitu memberikan hukuman terhadap pelanggar. Karena itu, P. Nicolai dalam Ridwan HR mengungkapkan pada umumnya dalam berbagai peraturan perundang-undangan, hukuman berupa denda ini telah ditentukan mengenai jumlah yang dapat dikenakan kepada pihak yang melanggar ketentuan. Di dalam Algemene bepalingen van administratief dinyatakan bahwa denda administratif hanya dapat diterapkan atas dasar kekuatan wewenang yang diatur dalam undang-undang dalam arti formal). ${ }^{11}$ Senada dengan itu, Philipus M. Hadjon menegaskan bahwa untuk pengenaan

8 Lihat dalam Herma Yanti \& Chinthia Andari, Peranan Badan Pengelola Pajak dan Retribusi Daerah Dalam Mengoptimalkan Penerimaan Pajak Bumi dan Bangunan di Kabupaten Muaro Jambi, Jurnal Ilmiah Universitas Batanghari Jambi Vol.17 no.3, (2017) : 86

${ }^{9}$ Daryanto, Kamus Lengkap Bahasa Indonesia, (Surabaya : Apollo, 1998), hlm.572

10 Mukti Fajar dan Yulianto Achmad, Dualisme Penelitian Hukum Normatif dan Empiris, (Yogyakarta : Pustaka Pelajar, 2019), hlm. 283

${ }^{11}$ Ridwan HR , Hukum Administrasi Negara, (Jakarta: PT. Raja Grafindo Persada, 2014), hlm.317-318 
denda administrative harus atas dasar peraturan perundang-undangan yang tegas. ${ }^{12}$ Dengan demikian, hal ini berarti bahwa diperlukan pengaturan yang kuat dan jelas untuk penerapan sanksi adminsitrasi denda, baik kewenangannya maupun jumlah denda yang akan dikenakan.

Pengaturan tentang sanksi administrasi denda atas pelanggaran larangan pembuangan sampah yang ditetapkan dalam Pasal 47 huruf a sampai huruf m Perda Nomor 8 Tahun 2013, ketentuannya tertuang dalam Pasal 56 ayat (1) yang menyatakan bahwa setiap orang atau Badan yang melanggar ketentuan Pasal 47 dikenakan sanksi administrasi berupa : a. denda, b. uang paksa, dan c. pencabutan izin. Selanjutnya dalam ayat (2) dinyatakan bahwa tatacara dan pelaksanaan sanksi administrasi tersebut diatur dengan Peraturan Walikota. Tentang jumlah atau besaran denda yang dibebankan bagi pelanggar tidak ditemukan pengaturannya dalam Perda tersebut, tetapi diatur dalam Peraturan Walikota Nomor 84 Tahun 2018 yang tertuang dalam Pasal 8. Dalam pasal tersebut menentukan bahwa setiap orang atau badan yang melanggar ketentuan Perda Nomor 8 Tahun 2013 berupa:

1. Melanggar ketentuan sebagaimana dimaksud dalam Pasal 47 huruf $b$, huruf $f$, huruf $g$ dan huruf $m$ dikenakan sanksi administrasi berupa denda paling banyak Rp. 40.000.000,- (empat puluh juta rupiah).

2. Melanggar ketentuan sebagaimana dimaksud dalam Pasal 47 huruf a, huruf $d$, huruf $j$ dan huruf $k$ dikenakan sanksi administrasi berupa denda paling banyak Rp. 30.000.000,- (tiga puluh juta rupiah).

3. Melanggar ketentuan sebagaimana dimamsud dalam Pasal 47 huruf e huruf $h$, dan huruf i PerdaKota Jambi Nomor 8 tahun 2013 dikenakan sanksi administrasi berupa denda paling banyak Rp. 10.000.000,- (sepuluh puluh juta rupiah).

4. Melanggar ketentuan sebagaimana dimaksud dalam Pasal 47 huruf $\mathrm{c}$ dan huruf 1 dikenakan sanksi sesuai dengan ketentuan peraturan perundang-undangan.

5. Setiap orang atau badan yang tidak memenuhi ketentuan sebagaimana dimaksud pada ayat (1), ayat (2), ayat (3) dan ayat (4) dikenakan sanksi administratif berupa pencabutan izin usaha.

Berdasarkan ketentuan di atas, Peraturan Walikota ini belum mengatur secara secara jelas dan rinci besaran denda atas pelanggaran berbagai jenis larangan yang diatur dalam Pasal 47 Perda Nomor 8 Tahun 2013. Ketentuan tersebut menentukan besaran denda atas tiga kelompok dan hanya menentukan jumlah denda paling banyak berdasarkan pengelompokan jenis-jenis pelanggaran yang ditentukan. Besaran denda masing-masing kelompok ditetapkan dengan jumlah nominal yang tergolong tinggi, kelompok pertama dengan denda paling banyak Rp. 40.000.000,- (empat puluh juta rupiah), kelompok kedua dengan denda paling banyak Rp.30.000.000,- (tiga puluh juta rupiah) dan jenis pelanggaran kelompok ketiga dengan denda paling banyak 10.000.000,- (sepuluh juta rupiah).

Ketentuan secara jelas dan rinci tentang besaran denda kemudian dituangkan dalam Keputusan Kepala Dinas Lingkungan Hidup Kota Jambi Nomor 42 Tahun 2019 tentang Pedoman Penerapan Sanksi Administratif Besaran Denda Yang Dibayarkan Berdasarkan Kubikasi Sampah. Berdasarkan Lampiran I Keputusan DLH tersebut, besaran denda tersebut adalah sebagaimana tertera dalam tabel berikut:

Tabel 1. Jenis Pelanggaran dan Besaran Sanksi Administrasi Denda atas Pelanggaran larangan Pembuangan Sampah Berdasarkan Keputusan DLH Nomor 42 Tahun 2019 tentang Pedoman Penerapan Sanksi Administratif Besaran Denda Yang Dibayarkan Berdasarkan Kubikasi Sampah

\begin{tabular}{|c|c|c|}
\hline Pelanggaran & Jumlah Kubikasi & Besaran Denda \\
\hline Pasal 47 huruf $b$ : & a. $0,1 \mathrm{~s} / \mathrm{d} 1 \mathrm{M}$ kubik & Rp. 20.000.000,- \\
\hline Kegiatan impor sampah & $\begin{array}{l}\text { b. }>1 \mathrm{M} \text { kubik s/d } 2 \mathrm{M} \text { kubik } \\
\text { c. }>2 \mathrm{M} \text { kubik }\end{array}$ & $\begin{array}{l}\text { Rp. } 30.000 .000,- \\
\text { Rp. } 40.000 .000,-\end{array}$ \\
\hline Pasal 47 huruf f : & a. $1 \mathrm{M}$ kubik s/d $2 \mathrm{M}$ kubik & Rp. 20.000.000,- \\
\hline $\begin{array}{l}\text { Membuang Sampah ke TPS menggunakan kendaraan Bermotor lebih } \\
\text { dari } 1 \text { meter kubik }\end{array}$ & $\begin{array}{l}\text { b. } 2 \mathrm{M} \text { kubik s/d } 3 \mathrm{M} \text { kubik } \\
\text { c. } 3 \mathrm{M} \text { kubik }\end{array}$ & $\begin{array}{l}\text { Rp. } 30.000 .000,- \\
\text { Rp. } 40.000 .000,-\end{array}$ \\
\hline $\begin{array}{l}\text { Pasal } 47 \text { huruf } \mathrm{g} \text { : } \\
\text { Membakar sampah di jalan, jalur hijau, taman, sungai, saluran } \\
\text { drainase dan tempat umum lainnya. }\end{array}$ & $\begin{array}{l}\text { a. } 0,1 \mathrm{s.d} \text { 0,5 M kubik } \\
\text { b. }>0,5 \mathrm{~m} \text { kubik s/d } 1 \mathrm{M} \text { kubik } \\
\text { c. }>1 \mathrm{M} \text { kubik s/d } 2 \mathrm{M} \text { kubik } \\
\text { d. }>2 \mathrm{M} \text { kubik s/d } 4 \mathrm{M} \text { kubik } \\
\text { e. }>4 \mathrm{M} \text { kubik }\end{array}$ & $\begin{array}{l}\text { Rp. } 5.000 .000,- \\
\text { Rp. } 10.000 .000,- \\
\text { Rp. } 20.000 .000,- \\
\text { Rp. } 30.000 .000,- \\
\text { Rp. } 40.000 .000,-\end{array}$ \\
\hline $\begin{array}{l}\text { Pasal } 47 \text { huruf } m \text { : } \\
\text { Mengelola sampah yang menyebabkan pencemaran dan kerusakan } \\
\text { Lingkungan }\end{array}$ & & Rp. 40.000.000,- \\
\hline $\begin{array}{l}\text { Pasal } 47 \text { huruf a : } \\
\text { Memasukkan sampah ke daerah }\end{array}$ & $\begin{array}{l}\text { a. } 0,1 \mathrm{~s} / \mathrm{d} 0,25 \mathrm{M} \text { kubik } \\
\text { b. }>0,50 \mathrm{M} \text { kubik }\end{array}$ & $\begin{array}{ll}\text { Rp. } & 3.000 .000,- \\
\text { Rp. } & 5.000 .000,-\end{array}$ \\
\hline
\end{tabular}


Pasal 47 huruf $d$ :

Membuang, menumpuk, menyimpan sampah atau bangkai binatang di jalan, jalur hijau, taman, sungai, fasilitas umum dan tempat lainnya yang sejenis.

Pasal 47 huruf $\mathrm{j}$ :

Membuang Sampah di luar TPS atau lokasi pembuangan sampah

Pasal 47 huruf k :

Membuang sampah di TPS di luar waktu yang telah ditentukan.

Pasal 47 huruf e :

Membuang sampah atau kotoran lainnya dari atas kendaraan.

Pasal 47 huruh h :

Membuang air besar di jalan, jalur hijau, taman, sungai, saluran drainase dan tempat umum.

Pasal 47 huruf i :

Mengeruk atau mengais sampah di TPS kecuali petugas c. >0,75 M kubik

d. $>1$ M kubik

e. > 1,5 M kubik

f. > $1 \mathrm{M}$ kubik s/d $2 \mathrm{M}$ kubik

g. > 2 M kubik

a. 0,1 s/d 0,25 M kubik

b. > 0,50 M kubik

c. >0,75 M kubik

d. > 1 M kubik

e. $>1 \mathrm{M}$ kubik s/d $2 \mathrm{M}$ kubik

f. > $2 \mathrm{M}$ kubik s/d $4 \mathrm{M}$ kubik

a. 0,1 s/d 0,25 M kubik

b. >0,50 M kubik

c. >0,75 M kubik

d. > 1 M kubik

e. > $1 \mathrm{M}$ kubik s/d $2 \mathrm{M}$ kubik

f. $>2 \mathrm{M}$ kubik s/d $4 \mathrm{M}$ kubik

a. 0,1 s/d 0,25 M kubik

b. >0,50 M kubik

c. >0,75 M kubik

d. > 1 M kubik

e. $>1 \mathrm{M}$ kubik s/d $2 \mathrm{M}$ kubik

f. > $2 \mathrm{M}$ kubik s/d $4 \mathrm{M}$ kubik

a. $0,1 \mathrm{~s} / \mathrm{d} 0,5 \mathrm{Kg}$

b. $>0,5 \mathrm{Kg} \mathrm{s} / \mathrm{d} 1 \mathrm{Kg}$

c. $>1 \mathrm{Kg}$
Rp. 7.500.000,-

Rp. 10.000.000,-

Rp. 15.000.000,-

Rp. 20.000.000,-

Rp. 30.000.000,-

Rp. 3.000.000,-

Rp. 5.000.000,-

Rp. 7.500.000,-

Rp. 10.000.000,-

Rp. 20.000.000,-

Rp. 30.000.000,-

Rp. 3.000.000,-

Rp. 5.000.000,-

Rp. 7.500.000,-

Rp. 10.000.000,-

Rp. 20.000.000,-

Rp. 30.000.000,-

Rp. 3.000.000,-

Rp. 5.000.000,-

Rp. 7.500.000,-

Rp. 10.000.000,-

Rp. 20.000.000,-

Rp. 30.000.000,-

Rp. 1.000.000,-

Rp. 5.000.000,-

Rp. 10.000.000,-

Rp. 10.000.000,-

Sumber: DLH Kota Jambi
a. $0,1 \mathrm{~s} / \mathrm{d} 0,1 \mathrm{Kg}$
b. $>1 \mathrm{Kg} \mathrm{s} / \mathrm{d} 5 \mathrm{Kg}$
c. $>5 \mathrm{Kg}$
Rp. 1.000.000,-
Rp. 5.000.000,-
Rp.10.000.000,-

Berdasarkan uraian di atas terlihat bahwa pengaturan sanksi administrasi denda dalam Perda Nomor 8 Tahun 2013 tidak disertai dengan pengaturan tentang besaran denda yang dapat dibebankan terhadap pelanggarnya. Besaran denda tersebut diatur dalam Peraturan Walikota Nomor 84 Tahun 2018 tentang Tatacara Penerapan Sanksi Administrasi Peraturan Daerah Kota Jambi Nomor 8 Tahun 2013 tentang Pengelolaan Sampah. Pengaturan besaran denda administrasi melalui Peraturan Walikota tentunya kurang tepat, karena Pasal Pasal 56 ayat (2) yang mendelegasikan kewenangan pengaturan dalam Peraturan Walikota hanya mendelegasikan pengaturan tentang tatacara pelaksanaan sanksi administrasi. Karena itu, sesuai dengan fungsinya sebagai peraturan pelaksana dari Perda, mestinya dalam Pearturan Walikota hanya memuat pengaturan sesuai yang didelegasikan.

Selain itu, pengaturan besaran denda melalui Peraturan Walikota tentunya juga kurang memiliki dasar yang kuat dibandingkan dengan pengaturan dalam Perda. Pemberian sanksi denda ini merupakan ketentuan yang memberi beban bagi masyarakat, maka seharusnya jumlah denda maksimum yang dapat dijatuhkan terhadap pelanggar terlebih dahulu diatur dalam Perda karena Perda dibentuk dengan melibatkan masyarakat melalui DPRD dan Kepala Daerah (dalam hal ini Walikota), sehingga lebih kuat kedudukannya. Baru selanjutnya diatur dalam Peraturan Walikota secara jelas dan rinci tatacara pelaksanaan sanksi serta besaran denda yang dikenakan terhadap pelanggaran yang dilakukan. Begitu juga penentuan besaran sanksi denda dalam bentuk Keputusan Dinas Lingkungan Hidup ini menurut peneliti juga kurang tepat dari segi penormaannya. Karena dari aspek norma hukum, keputusan merupakan beschikking yang sifatnya individual atau hanya ditujukan bagi orang tertentu saja, sedangkan Keputusan ini ditujukan bagi semua pelanggar. Karena itu sebaiknya ketentuan tersebut dituangkan langsung dalam Peraturan Walikota sesuai yang diamanahkan Pasal 56 ayat (2) PerdaNomor 8 Tahun 2013. Meskipun demikian, selama ketentuan tersebut masih diberlakukan tentunya masih tetap digunakan sebagai pedoman dalam penerapan sanksi. 


\section{Peran Dinas Lingkungan Hidup Kota Jambi Dalam Penerapan Sanksi Administrasi Denda Terhadap Pelanggaran Larangan Pembuangan Sampah Berdasarkan PerdaNomor 8 Tahun 2013 tentang Pengelolaan Sampah.}

Penerapan sanksi administrasi merupakan bagian penting dalam penegakan hukum admini strasi. Hal ini didasarkan atas pemikiran bahwa tidak ada artinya memasukkan adanya kewajiban maupun larangan di dalam normanorma hukum pemerintahan, apabila norma-norma tersebut tidak dapat dipatuhi oleh warga masyarakat, karena itu diperlukan adanya proses penegakan hukum pemerintahan melalui penerapan sanksi administrasi.

Penerapan sanksi administrasi tersebut dilakukan dalam hal terjadi pelanggaran hukum yang dilakukan oleh warga masyarakat terhadap norma-norma hukum pemerintahan. Penegakan hukum pemerintahan tersebut wajib atau harus dilakukan oleh pemerintah agar pelanggaran terhadap hal tersebut dapat segera dihentikan. Sebagaimana dikemukakan Aminudin Ilmar bahwa sekecil apapun pelanggaran yang dilakukan warga masyarakat harus segera dilakukan tindakan penegakan hukum pemerintahan agar norma-norma hukum pemerintahan dapat ditaati dengan baik oleh warga masyarakat. Dengan kata lain bahwa pada dasarnya tidak dibolehkan adanya perbuatan yang menyimpang dari aturan yang telah ditetapkan oleh pemerintah agar ketertiban dalam masyarakat selalu dapat terjaga dengan baik. ${ }^{13}$

Upaya pemerintah Kota Jambi untuk menegakkan ketentuan dalam Perda Nomor 8 Tahun 2013 dengan ditetapkannya Peraturan Walikota Nomor 84 Tahun 2018 pada Tanggal 31 Desember 2018, memberikan wewenang kepada DLH Kota Jambi untuk melaksanakan penerapan sanksi administrasi denda khususnya dalam hal ini terhadap pelanggaran larangan pembuangan sampah yang telah ditentukan dalam Perda. Karena itu peran DLH sangat menentukan terlaksananya penerapan sanksi administrasi denda yang telah ditentukan dalam Perda tersebut. Sebelumnya dari hasil penelitian M. Muslih mengungkapkan bahwa pelaksanaan Perda tentang Pengelolaan Sampah yang terkait tentang ancaman sanksi yang diatur dalam Pasal 56 belum menjadi perhatian serius pemerintah kota". ${ }^{14}$

Peran DLH dalam penerapan sanksi denda administratif terhadap pelanggaran larangan pembuangan sampah tersebut telah dilakukan mulai Tahun 2019. Data penerapan sanksi yang telah dilakukan dari Tahun 2019 hingga penelitian ini dilakukan (bulan Juni Tahun 2020) dapat dilihat dalam tabel berikut:

Tabel 2. Penerapan Sanksi Administrasi Denda oleh DLH Kota Jambi Terhadap Pelanggaran Larangan Pembuangan Sampah dari Tahun 2019 s.d. Bulan Juni 2020

\begin{tabular}{|c|c|c|c|c|}
\hline No & Tanggal & Lokasi & Pelanggaran : & $\begin{array}{c}\text { Jumlah Denda } \\
\text { dikenakan (Rp) \& } \\
\text { Keputusan Denda }\end{array}$ \\
\hline 1. & $\begin{array}{l}\text { 05 Januari } \\
2019\end{array}$ & $\begin{array}{l}\text { Simpang Komplek } \\
\text { Arsenal Jl. Bangka } \\
\text { RT } 21 \text { Kebun Handil } \\
\text { Kec. Jelutung }\end{array}$ & $\begin{array}{l}\text { - Pasal } 47 \text { huruf } \mathrm{f} \text { : } \\
\text { Membuang sampah ke TPS dengan menggunakan } \\
\text { kendaraan bermotor yang volumenya lebih dari } 1 \\
\text { (satu) meter kubik (Pasal } 47 \text { huruf } \\
\text { - Pasal } 47 \text { huruf k } \\
\text { Membuang sampah di TPS di luar waktu yang } \\
\text { ditentukan. }\end{array}$ & $\begin{array}{l}\text { Rp. 20.000.000,- } \\
\text { (Keputusan Kepala } \\
\text { DLH No.26 Tahun } \\
\text { 2019) }\end{array}$ \\
\hline 2. & $\begin{array}{l}\text { 14 Januari } \\
2019\end{array}$ & $\begin{array}{l}\text { TPS depan } \\
\text { Perumahan Citraland } \\
\text { NGK Mayang }\end{array}$ & $\begin{array}{l}\text { - Pasal } 47 \text { huruf } \mathrm{f} \text { : } \\
\text { Membuang sampah ke TPS menggunakan } \\
\text { kendaraan yang volumenya lebih dari } 1 \mathrm{M} \text { kubik } \\
\text { - Pasal } 47 \text { huruf j: } \\
\text { Membuang sampah di luar tempat/lokasi } \\
\text { pembuangan yang telah ditentukan } \\
\text { - Pasal } 47 \text { huruf k: } \\
\text { Membuang sampah di TPS di luar waktu yang } \\
\text { ditentukan. }\end{array}$ & $\begin{array}{l}\text { Rp. 10.000.000,- } \\
\text { (Keputusan Kepala } \\
\text { DLH No.45 Tahun } \\
\text { 2019) }\end{array}$ \\
\hline 3. & $\begin{array}{l}11 \text { Februari } \\
2019\end{array}$ & $\begin{array}{l}\text { Jl. Orang kayo Pingai } \\
\text { Kec. Jambi Timur }\end{array}$ & $\begin{array}{l}\text { - Pasal } 47 \text { huruf j: } \\
\text { Membuang sampah di luar TPS/lokasi } \\
\text { pembuangan yang telah ditetapkan } \\
\text { - Pasal } 47 \text { huruf k: } \\
\text { Membuang sampah di luar waktu yang telah } \\
\text { ditentukan }\end{array}$ & $\begin{array}{l}\text { Rp. 3.000.000,-(Kep. } \\
\text { Kepala DLH Kota } \\
\text { Jambi No.59 Tahun } \\
\text { 2019) }\end{array}$ \\
\hline
\end{tabular}




\begin{tabular}{|c|c|c|c|c|}
\hline 4. & $\begin{array}{l}21 \text { Sept } \\
2019\end{array}$ & $\begin{array}{l}\text { Jl. Pattimura Kel. } \\
\text { Beliung Kec. Alam } \\
\text { Barajo }\end{array}$ & $\begin{array}{l}\text { - Pasal } 47 \text { huruf f: } \\
\text { Membuang sampah ke TPS menggunakan } \\
\text { kendaraan yang volumenya lebih dari } 1 \mathrm{M} \text { kubik } \\
\text { - Pasal } 47 \text { huruf j: } \\
\text { Membuang sampah di luar tempat/lokasi } \\
\text { pembuangan yang ditentukan. }\end{array}$ & $\begin{array}{l}\text { Rp. 20.000.000,- } \\
\text { (Kep. Kepala DLH Kota } \\
\text { Jambi No.177 Tahun } \\
\text { 2019). }\end{array}$ \\
\hline 5. & $\begin{array}{l}20 \text { Des } \\
2019\end{array}$ & $\begin{array}{l}\text { Jl. TP. Sriwijaya Kel. } \\
\text { Rawasari Kec. Alam } \\
\text { Barajo }\end{array}$ & $\begin{array}{l}\text { - Pasal } 47 \text { huruf } \\
\text { Membuang sampah di luar TPS dengan } \\
\text { menggunakan kendaraan bermotor } 3 \mathrm{~kg} \\
\text { - -Pasal } 47 \text { huruf } \\
\text { Membuang sampah di luar TPS di luar waktu yang } \\
\text { telah ditentukan }\end{array}$ & $\begin{array}{l}\text { Rp. 500.000,- } \\
\text { (Kep. Kepala DLH Kota } \\
\text { Jambi No.221 Tahun } \\
\text { 2019). }\end{array}$ \\
\hline 6. & $\begin{array}{l}20 \text { Des } \\
2019\end{array}$ & $\begin{array}{l}\text { Jl. TP. Sriwijaya Kel. } \\
\text { Rawasari Kec. Alam } \\
\text { Barajo }\end{array}$ & $\begin{array}{l}\text { - Pasal } 47 \text { huruf } \\
\text { Membuang sampah di luar TPS dengan } \\
\text { menggunakan kendaraan bermotor } 3 \mathrm{~kg} \\
\text { - Pasal } 47 \text { huruf } \\
\text { Membuang sampah di luar TPS di luar waktu yang } \\
\text { telah ditentukan. }\end{array}$ & $\begin{array}{l}\text { Rp. 500.000,- } \\
\text { (Kep. Kepala DLH Kota } \\
\text { Jambi No.222 Tahun } \\
\text { 2019). }\end{array}$ \\
\hline 7. & 20 Jan 2020 & $\begin{array}{l}\text { Jl. Untung Suropati } \\
\text { Kel. Jelutung Kec. } \\
\text { Jelutung. }\end{array}$ & $\begin{array}{l}\text { Membuang sampah di luar TPS atau lokasi } \\
\text { pembuangan sampah dengan menggunakan } \\
\text { gerobak motor } .0,50 \text { m kubik. }\end{array}$ & $\begin{array}{l}\text { Rp.5.000.000,- } \\
\text { (Kep. Kepala DLH Kota } \\
\text { Jambi No.64 Tahun } \\
\text { 2020) }\end{array}$ \\
\hline 8. & $\begin{array}{l}27 \text { Jan } \\
2020\end{array}$ & $\begin{array}{l}\text { Jl. KH. Ismail Malik } \\
\text { Kel. Mayang } \\
\text { Mangurai Kec. Alam } \\
\text { Barajo }\end{array}$ & - Membuang sampah di luar waktu yang ditentukan & $\begin{array}{l}\text { Rp. 3.000.000,-(Kep. } \\
\text { Kepala DLH Kota } \\
\text { Jambi No.75 Tahun } \\
\text { 2020) }\end{array}$ \\
\hline 9. & $\begin{array}{l}21 \text { februari } \\
2020\end{array}$ & $\begin{array}{l}\text { Jl. Untung Suropati } \\
\text { Kel. Jelutung Kec. } \\
\text { Jelutung }\end{array}$ & $\begin{array}{l}\text { - Membuang sampah di luar TPS atau lokasi } \\
\text { pembuangan sampah dengan menggunakan } \\
\text { kendaraan mobil mini bus sebanyak 0,1-0,25 meter } \\
\text { kubik }\end{array}$ & $\begin{array}{l}\text { Rp.5.000.000,-(Kep. } \\
\text { Kepala DLH Kota } \\
\text { Jambi No.90 Tahun } \\
2020\end{array}$ \\
\hline 10 & $\begin{array}{l}18 \text { Maret } \\
2020\end{array}$ & $\begin{array}{l}\text { Jl. Zaidi Saleh Kel. } \\
\text { Paal Merah Kec. Kota } \\
\text { Baru }\end{array}$ & $\begin{array}{l}\text { - Membuang sampah di luar TPS } \\
\text { - } \text { Membuang sampah di luar waktu yang telah } \\
\text { ditentukan menggunakan kendaraan mobil pick up } \\
\text { lebih kurang 0,1-0,25 m kubik. }\end{array}$ & $\begin{array}{l}\text { 3.000.000,- } \\
\text { Kep. Kepala DLH Kota } \\
\text { Jambi No. } 108 \text { Tahun } \\
2020\end{array}$ \\
\hline
\end{tabular}

Sumber: DLH Kota Jambi.

Berdasarkan data pada tabel di atas, terlihat bahwa dari Tahun 2019 hingga penelitian ini dilakukan ( bulan Juni 2020), penerapan sanksi administrasi denda oleh DLH Kota Jambi telah dilaksanakan sebanyak 10 (sepuluh) kali. Jumlah denda yang diterapkan paling banyak Rp. 20.000.000,- (dua puluh juta rupiah) dan paling sedikit Rp. 500.000,- (Lima ratus ribu rupiah). Penjatuhan sanksi tersebut dituangkan dalam Keputusan Kepala DLH Kota Jambi sesuai ketentuan yang berlaku.

Penerapan denda pertama dijatuhkan sebesar Rp. 20.000.000,- (dua puluh juta rupiah) pada awal Januari 2019 terhadap seorang warga yang tertangkap tangan petugas di TPS melanggar larangan membuang sampah ke TPS dengan menggunakan kendaraan bermotor yang volumenya lebih dari 1 (satu) meter kubik, dan membuang sampah di TPS di luar waktu yang telah ditentukan (melanggar Pasal 47 huruf $\mathrm{f}$ dan huruf k Perda Nomor 8 Tahun 2013). Tindakan tersebut ancaman dendanya masing-masing sebesar Rp. 20.000.000,- (dua puluh juta rupiah).

Berdasarkan hasil wawancara dengan Agustiawan, staf bagian penegakan hukum pada DLH Kota Jambi bahwa: "awalnya terhadap yang bersangkutan dikenakan denda oleh DLH sebesar Rp. 40.000.000,- (empat puluh juta rupiah), namun karena yang bersangkutan tidak bersedia membayarnya, berkas perkaranya dilimpahkan ke Pengadilan Umum dan pengadilan menjatuhkan sanksi denda sebesar Rp. 20.000.000,-“" ${ }^{-15}$. Penerapan denda melalui Pengadilan ini dilakukan berdasarkan ketentuan Pasal 57 ayat (1) Perda Nomor 8 Tahun 2013, yaitu apabila pelanggar tidak bersedia melaksanakan ketentuan sanksi administrasi denda yang dijatuhkan, maka dikenakan sanksi pidana melalui pengadilan.

Penerapan sanksi denda kedua dijatuhkan sebesar Rp. 10.000.000,- (sepuluh juta rupiah) pada Tanggal 14 Januari 2019 terhadap warga atas pelanggaran yang dilakukan berupa (1) membuang sampah ke TPS menggunakan kendaraan bermotor yang volumenya lebih dari $1 \mathrm{M}$ kubik, (2) membuang sampah di luar tempat/lokasi pembuangan yang telah ditentukan, dan (3) Membuang sampah di TPS di luar waktu yang ditentukan (melanggar Pasal 47 huruf f, 
huruf j dan k). Berdasarkan Pedoman Penerapan Besaran Denda Yang ditetapkan dalam Keputusan Kepala DLH Kota Jambi Nomor 48 Tahun 2019, besaran denda yang ditetapkan untuk pelanggaran huruf f sebesar Rp. 20.000.000,,.Kemudian untuk pelanggaran huruf $\mathrm{j}$ dan $\mathrm{k}$, jika volume sampahnya lebih dari $1 \mathrm{M}$ kubik, besaran dendanya masingmasing yaitu Rp. 10.000.000,- (sepuluh juta rupiah). Dalam hal ini, meskipun tidak dikenakan akumulasi denda, tetapi mestinya terhadap pelanggar dikenakan sanksi denda yang jumlahnya paling besar, yaitu Rp. 20.000.000,- (dua puluh juta rupiah), karena itu dalam hal ini terlihat besaran denda yang dikenakan tidak sesuai pedoman yang ditetapkan.

Penerapan sanksi denda yang ketiga dijatuhkan sebesar Rp.3.000.000,- (tiga juga rupiah) pada Tanggal 11 februari 2019 atas pelanggaran berupa (1) membuang sampah di luar tempat/lokasi pembuangan yang telah ditetapkan dan (2) membuang sampah di luar waktu yang telah ditentukan (melanggar Pasal 47 huruf $\mathrm{j}$ dan huruf $\mathrm{k}$ ) dengan ancaman denda untuk setiap pelanggaran yaitu Rp.3.000.000,- (tiga juga rupiah). Dalam hal ini besaran denda yang dikenakan tersebut sesuai dengan pedoman yang telah ditentukan.

Penerapan sanksi denda yang keempat dijatuhkan sebesar Rp.20.000.000,- (dua puluh juta rupiah,-) pada tanggal 21 September 2019 terhadap warga atas pelanggaran berupa: (1) membuang sampah di luar TPS dengan menggunakan kendaraan bermotor yang volumenya lebih dari 1 meter kubik dan (2) membuang sampah di luar waktu yang telah ditentukan (melanggar Pasal 47 huruf $f$ dan huruf k). Dari dua pelanggaran tersebut terhadap pelanggar telah dikenakan ancaman denda yang paling besar nilainya yaitu Rp. 20.000.000,- (dua puluh juta rupiah) sesuai dengan pedoman yang ditentukan.

Penerapan sanksi denda yang kelima dan keenam dijatuhkan pada Tanggal 20 Desember 2019 kepada dua orang pelanggar masing-masing sebesar 500.000,- (lima ratus ribu rupiah). keduanya sama-sama melanggar Pasal $47 \mathrm{j}$ yaitu membuang sampah di luar TPS dengan menggunakan kendaraan bermotor dan Pasal 47 huruf k, yaitu membuang sampah di luar waktu yang ditentukan dengan ancaman denda paling rendah sebesar Rp.3.000.000,- (tiga juta rupiah). Terhadap hal ini, berdasarkan informasi yang diperoleh dari Agustiawas, staf Penegakan Hukum pada DLH Kota Jambi mengatakan bahwa "sanksi terhadap kedua pelanggar tersebut jumlahnya kecil karena kedua pelanggar hanya membuang sampah dengan volume yang kecil yaitu masing-masing 1 kantong plastik". Hal ini tentunya kurang sesuai dengan besaran denda yang terdapat dalam pedoman penjatuhan sanksi, dimana untuk ukuran paling rendah dengan volume $0,1 \mathrm{M}$ kubik ditetapkan sebesar Rp. 3000.000,- (tiga juta rupiah), namun yang dijatuhkan hanya Rp.500.000,- (lima ratus ribu rupiah).

Penerapan sanksi denda yang ketujuh diterapkan Tanggal 20 Januari 2020 sebesar 5.000.000,- (lima juta rupiah) kepada salah seorang warga karena atas pelanggaran membuang sampah di luar TPS atau lokasi pembuangan sampah dengan menggunakan gerobak motor $>0,50 \mathrm{~m}$ kubik (melanggar ketentuan pasal 47 huruf j) dengan ancaman denda sebesar Rp. 5.000.000,- (lima juta rupiah). Besaran denda yang dijatuhkan tersebut sesuai dengan yang tertuang dalam pedoman penerapan sanksi denda yang ditetapkan.

Penerapan sanksi denda yang kedelapan diterapkan Tanggal 27 Januari 2020 sebesar 3.000.000,- (tiga juta rupiah) kepada salah seorang warga atas pelanggaran yaitu membuang sampah di luar waktu yang ditentukan ( melanggar ketentuan pasal 47 huruf k). Dalam hal in besaran denda yang dijatuhkan tersebut sesuai dengan pedoman penerapan sanksi yang telah ditetapkan.

Penerapan sanksi denda yang kesembilan diterapkan Tanggal 21 Februari 2020 sebesar 5.000.000,- (lima juta rupiah) kepada salah seorang warga atas tindakan pelanggaran membuang sampah di luar TPS yang telah ditentukan menggunakan kendaraan mobil mini bus sebanyak 0,1-0,25 meter kubik. Besaran denda yang dijatuhkan tersebut dapat dikatakan sesuai dengan ketentuan pedoman penerapan besaran denda yang ditetapkan..

Kemudian penerapan sanksi denda kesepuluh dijatuhkan sebesar 3.000.000,- (tiga juta rupiah) kepada salah seorang warga atas pelanggaran larangan membuang sampah di luar TPS atau lokasi pembuangan sampah dan membuang sampah di luar waktu yang waktu yang ditentukan menggunakan kendaraan mobil pick up lebih kurang 0,1-0,25m kubik . Besaran denda tersebut dapat dikatakan sesuai dengan ketentuan.

Berdasarkan uraian di atas, dari 10 penerapan sanksi denda yang telah dilakukan DLH Kota Jambi tersebut, umumnya besaran denda yang diterapkan terhadap pelanggar sesuai dengan besaran denda yang ditetapkan dalam Pedoman Penerapan Sanksi Administrasi Besaran Denda Yang Dibayarkan sebagaimana tertuang dalam Keputusan Kepala DLH Kota Jambi Nomor 42 Tahun 2019. Pelanggar yang melanggar beberapa larangan, dikenakan jumlah denda yang paling besar dari pelanggaran tersebut. Dari jumlah tersebut terdapat tiga pelanggar yang dikenakan sanksi denda yang belum sesuai dengan ketentuan dalam pedoman penerapan besaran denda karena lebih rendah dari yang ditentukan, seperti terlihat pada penerapan sanksi denda kedua, kelima dan keenam di atas.

Dalam hal ini berdasarkan hasil wawancara dengan Bapak Hermanto selaku Kasi Pengendalian dan Pengawasan Persampahan DLH Kota Jambi mengungkapkan bahwa "untuk penerapan sanksi tersebut selain pertimbangan kapasitas atau ukuran sampah yang dibuang, juga disertai pertimbangkan faktor lain seperti kondisi dan 
keadaan ekonomi pelanggar, sehingga tidak memungkinkan dijatuhi sanksi yang besar sesuai keetentuan". ${ }^{16}$ Dalam hal ini pertimbangan-pertimbangan lain tersebut memang tidak bisa dikesampingkan, namun di sisi lain tidak sesuai dengan pedoman yang telah ditetapkan DLH sebelumnya tentang besaran denda yang dibayarkan. Karena itu perlu kiranya pedoman tentang besaran denda tersebut ditinjau kembali, sebab penetapan besaran denda yang tinggi tentunya akan sulit diimplementasikan sesuai yang ditentukan, sehingga hal ini berpengaruh pada kurang optimalnya peran DLH.

Selanjutnya apabila kesepuluh kali penerapan sanksi denda tersebut dilihat dari rentang waktu penerapan setiap bulannya dari awal Tahun 2019 sampai dengan penelitian ini dilakukan (bulan Juni 2020), maka dapat dijabarkan pada tabel berikut :

Tabel 3. Rekapitulasi Penerapan Sanksi Administrasi Denda oleh DLH Kota Jambi setiap bulannya dari Bulan Januari 2019 s.d Bulan Juni 2020

\begin{tabular}{cccc}
\hline No & Bulan & Tahun 2019 & Tahun 2020 \\
\hline 1. & Januari & 2 kali & 2 kali \\
2. & Februari & 1 kali & 1 kali \\
3. & Maret & - & 1 kali \\
4. & April & - & - \\
5. & Mai & - & - \\
6. & Juni & - & - \\
7. & Juli & - & x \\
8. & Agustus & - & x \\
9. & September & 1 kali & x \\
10. & Oktober & - & x \\
11. & November & - & X \\
12. & Desember & 2 kali & 4 kali \\
\hline
\end{tabular}

Sumber: hasil pengolahan data

\section{Keterangan:}

Tanda $(-) \quad=$ tidak ada penerapan denda

Tanda $(\mathrm{x}) \quad=$ belum ada data penelitian

Berdasarkan tabel di atas, terlihat bahwa penerapan sanksi administrasi denda oleh DLH Kota Jambi selama Tahun 2019 diterapkan sebanyak enam kali yaitu 2 kali pada bulan januari, 1 kali pada bulan februari, selanjutnya selama bulan Maret hingga Agustus tidak terlihat sama sekali adanya penerapan sanksi denda, dan baru terlihat lagi penerapannya pada bulan September sebanyak satu kali dan pada bulan Desember sebanyak 2 (dua) kali. Kemudian pada Tahun 2020, dari bulan Januari sampai Juni 2020, baru diterapkan sebanyak empat kali,yaitu 2 kali kali pada bulan Januari, 1 kali pada bulan Februari dan 1 kali pada bulan Maret, selanjutya dari bulan April hingga Juni tidak ada penerapan sanksi denda yang dilakukan.

Hal ini menunjukkan bahwa penerapan sanksi denda ini tentunya belum sebanding dengan tingkat pelanggaran yang terjadi. Berdasarkan pengamatan peneliti tindakan pelanggaran atas larangan tidak hanya terjadi sesekali saja melainkan dapat terlihat setiap hari. Sementara penerapan sanksi administrasi denda oleh DLH tidak selalu ada setiap bulannya. Dari pengamatan terhadap beberapa titik tempat pembuangan sampah yang terdapat di Kota Jambi, ditemui adanya pelanggaran yang dilakukan terutama pelanggaran terhadap waktu pembuangan sampah yang ditentukan, padahal dalam Peraturan Walikota Nomor 84 Tahun 2018 telah ditentukan dengan tegas tentang waktu pembuangan sampah ditetapkan dari jan 18.00 sampai dengan jam 06.00 WIB. Selain itu juga terlihat pelanggaran terhadap larangan pembuangan sampah dari atas kendaraan serta pelanggaran terhadap larangan pembuangan sampah di luar tempat pembuangan sampah yang ditentukan. Dengan belum sebandingnya jumlah penerapan sanksi administrasi denda dengan tingkat pelanggaran yang terlihat di lapangan, maka sesuai dengan tolok ukur yang digunakan menunjukkan bahwa peran DLH Kota Jambi dalam penerapan sanksi denda atas pelanggaran larangan pembuangan sampah berdasarkan Perda Nomor 8 Tahun 2013 dapat dikatakan belum optimal.

Selanjutnya apabila jenis tindakan pelanggaran larangan yang telah dikenakan sanksi denda tersebut dikaitkan dengan jenis-jenis larangan yang diatur dalam Pasal 47 Perda Nomor 8 Tahun 2013, maka tindakan tindakan pelanggaran yang telah dijatuhi sanksi oleh DLH Kota Jambi dapat dilihat pada tabel berikut : 
Herma Yanti et al, Peran Dinas Lingkungan Hidup Kota Jambi dalam Penerapan Sanksi Administrasi Denda Berdasarkan Peraturan Daerah Nomor 8 Tahun 2013 Tentang Pengelolaan Sampah

Tabel 4. Jenis-Jenis Larangan Pembuangan Sampah Berdasarkan Perda Nomor 8 Tahun 2013 dan Jenis-jenis Tindakan Pelanggaran yang telah dikenakan Sanksi Administrsai Denda oleh DLH Kota Jambi

\section{No Jenis-Jenis Larangan Pembuangan Sampah Berdasarkan Perda No.8 Tahun 2013}

Pelanggaran yang telah

1. Memasukkan sampah ke daerah

2. Melakukan kegiatan impor sampah

3. Mencampur sampah dengan limbah berbahaya

4. Membuang, menumpuk, menyimpan sampah atau bangkai binatang di jalan, jalur hijau, taman, sungai, fasilitas umum dan tempat lainnya yang sejenis;

5. Membuang sampah dan/atau kotoran lainnya dari atas kendaraan;

6. Membuang sampah ke TPS dengan menggunakan kendaraan bermotor yang volumenya lebih dari 1 (satu) kubik;

7. Membakar sampah dan/atau kotoran lainnya di jalan, jalur hijau, taman, sungai, saluran drainase dan tempat-tempat umum lainnya;

8. Membuang air besar (hajar besar) di jalan, jalur hijau, taman, sungai, saluran drainase dan tempat umum;

9. Mengeruk atau mengais sampah di TPS, kecuali oleh petugas untuk kepentingan dinas;

10. Membuang sampah di luar tempat/lokasi pembuangan yang telah ditetapkan;

11. Membuang sampah di TPS di luar waktu yang telah ditentukan;

12. Membuang sampah di TPS klinis dan limbah B3 lainnya ke TPS dan TPA;

13. Mengelola sampah yang menyebabkan pencemaran dan/atau perusakan lingkungan. dikenakan Sanksi Ada Belum Ada

Sumber: Hasi Pengolahan Data

Berdasarkan tabel di atas, terlihat bahwa dari 13 jenis larangan yang diatur Pasal 47 Perda Nomor 8 Tahun 2013, pengenaan sanksi denda oleh DLH Kota Jambi baru diterapkan terhadap tiga jenis tindakan pelanggaran yaitu: (1) tindakan pelanggaran membuang sampah ke TPS dengan menggunakan kendaraan bermotor yang volumenya lebih dari 1 (satu) meter kubik, (2) tindakan membuang sampah di luar TPS/ tempat pembuangan sampah yang ditentukan, dan (3) tindakan membuang sampah di TPS di luar waktu yang ditentukan. Hal ini menjadi pertanyaan, apakah pelanggaran-pelanggaran yang terjadi hanya terhadap 3 hal tersebut?, tentu saja tidak. Karena berdasarkan observasi peneliti, selain tiga jenis tindakan di atas, tindakan pelanggaran-pelanggaran lainnya sering terlihat seperti pelanggaran terhadap larangan mengeruk atau mengais sampah di TPS selain oleh petugas untuk kepentingan dinas. Hal tersebut terlihat banyak dilakukan para pemulung. Padahal dalam Pasal 47 huruf i Perda Nomor 8 Tahun 2013 dengan tegas melarang setiap orang atau badan dilarang mengeruk atau mengais sampah di TPS, kecuali oleh petugas untuk kepentingan dinas. Ancaman denda untuk pelanggaran tersebut juga sudah dicantumkan, yaitu untuk ukuran 0,1 s.d 1 kg saja diancam denda Rp. 1.000.000,- (satu juta rupiah). Pelanggaran-pelanggaran tersebut terlihat di beberapa TPS di Kota Jambi seperti terlihat dalam gambar-gambar hasil penelitian berikut:

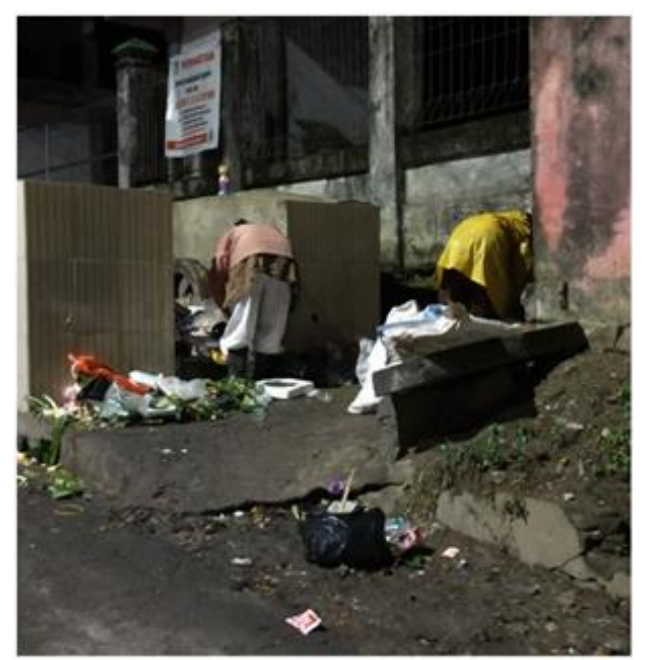

Tindakan pelanggaran terhadap larangan mengeruk/ mengais sampah di TPS Jln. Cokroaminoto Kota Jambi

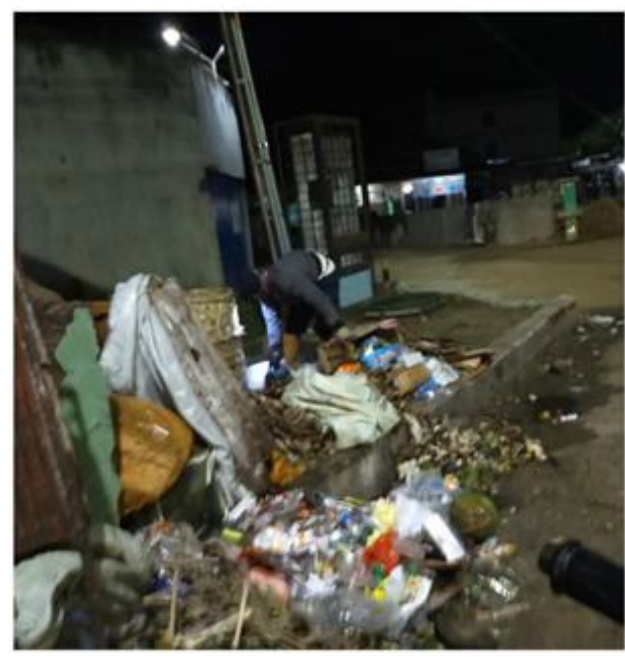

Tindakan pelanggaran mengorek/mengais sampah di TPS di Jalan Pattimura 
Herma Yanti et al, Peran Dinas Lingkungan Hidup Kota Jambi dalam Penerapan Sanksi Administrasi Denda Berdasarkan Peraturan Daerah Nomor 8 Tahun 2013 Tentang Pengelolaan Sampah

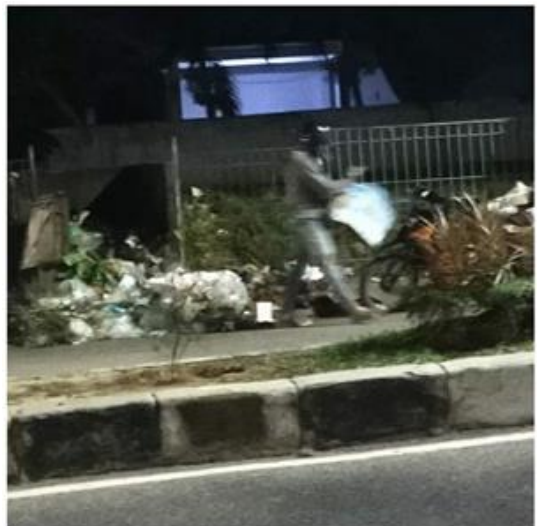

Tindakan pelanggaran terhadap larangan mengais sampahdi TPS di Jl. H. Rahman Hakim.

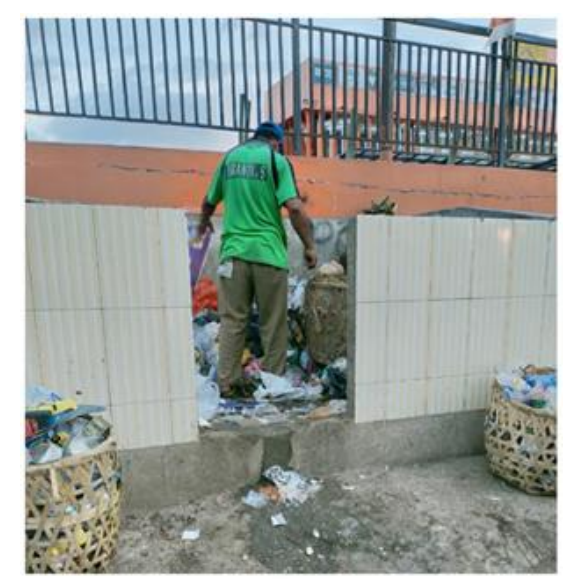

Tindakan pelanggaran terhadap larangan mengeruk /mengais sampah, di TPS Jln. Patimura Kota Jambi

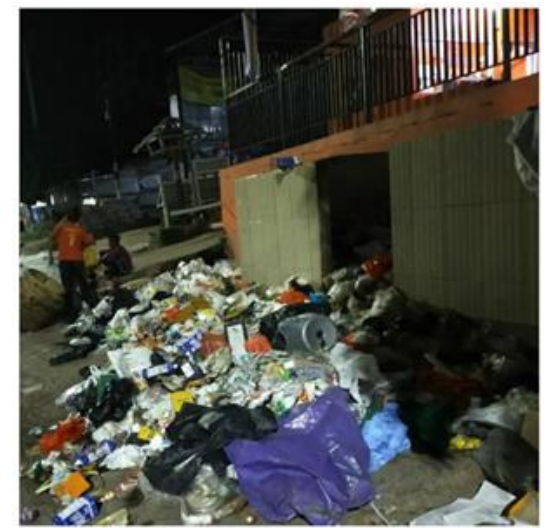

Tindakan pelanggaran terhadap larangan mengais sampahdi TPS di TPS, Jln. Patimura

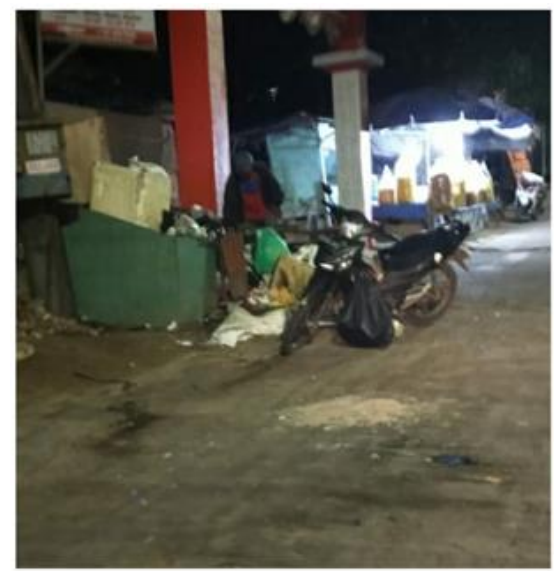

Tindakan pelanggaran terhadap larangan mengeruk/mengais sampah di TPS Kelurahan Rawasari Kota Jamb

Begitu juga pelanggaran-pelanggaran lainnya seperti yang dikemukakan oleh Bapak Hermanto selaku Kasi Pengendalian dan Pengawasan Persampahan DLH Kota Jambi, bahwa"Pelanggaran terhadap larangan impor sampah juga sudah sering terjadi seperti terlihat di dekat perbatasan Kota Jambi dengan daerah Kabupaten Muaro Jambi, tetapi untuk dilakukan pengenaan denda belum bisa diterapkan" ${ }^{17}$. Pernyataan tersebut dikuatkan oleh Azzkya Mursalim, Staf bagian Yustisi DLH Kota Jambi yang mengungkapkan bahwa "terhadap pelaku impor sampah sudah pernah dilakukan pengintaian, tetapi belum berhasil menemukan pelakunya ${ }^{18}$. Adanya pelanggaran yang disampaikan tersebut terbukti dari hasil observasi yang dilakukan ke lokasi yang disebutkan sebagaimana terlihat pada gambar berikut:
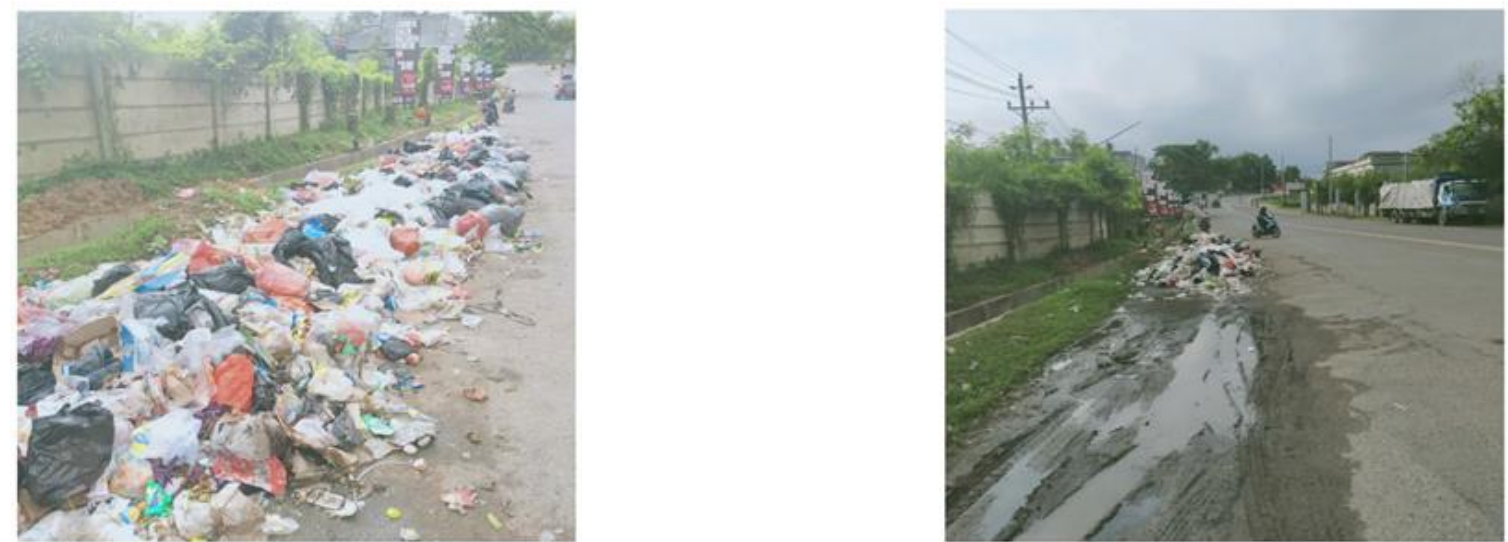

Bukti tindakan pelanggaran larangan Impor Sampah, Lokasi Simpang rimbo Kota Jambi.

\footnotetext{
${ }^{17}$ Hermanto, Kasi Pengendalian dan Pengawasan Persampahan DLH Kota Jambi, wawancara, 3 Juni 2020

${ }^{18}$ Azzkya Mursalim, Staf Bagian Yustisi Bidang Mobilisasi Persampahan DLH Kota Jambi, wawancara 24 Agustus 2020.
} 
Belum adanya penerapan sanksi denda administrasi terhadap jenis tindakan pelanggaran-pelanggaran tersebut, menunjukan belum optimalnya peran DLH Kota Jambi dalam penerapan sanksi denda terhadap pelanggaran larangan pembuangan sampah yang diatur dalam Perda Nomor 8 Tahun 2013. Di satu sisi hal ini dapat dimaklumi karena besarnya denda yang ditentukan tentunya akan sulit untuk menerapkannya apalagi terhadap tindakan pelanggaran yang dilakukan para pemulung yang melanggar larangan mengais sampah dengan ancaman denda yang tinggi. Namun di sisi lain, sebagaimana dikemukakan sebelumnya bahwa tidak ada artinya menentukan larangan terhadap masyarakat apabila pelanggaran terhadap larangan tersebut tidak dapat dikenakan sanksi yang telah ditentukan bagi pelanggarnya, karena itu, sekecil apapun pelanggaran yang dilakukan warga masyarakat semestinya segera dilakukan tindakan penegakan hukum agar norma-norma hukum yang telah ditetapkan dapat ditaati dengan baik oleh masyarakat.

Karena itu besaran denda yang telah ditentukan perlu ditinjau ulang dengan mempertimbangkan pelaksanaannya, sehingga dapat diterapkan untuk menghentikan terjadinya pelanggaran. Dengan demikian peran DLH dalam penerapan denda tidak hanya didasarkan atas adanya kewenangan penerapan sanksi yang telah diberikan, adanya pelaku yang melakukan pelanggaran serta adanya bukti-bukti pelanggaran, tetapi juga harus didukung dengan ketentuan tentang besaran denda dengan mempertimbangkan kemampuan dari pelanggarnya sehingga dapat diterapkan sebagaimana mestinya.

\section{SIMPULAN}

Berdasarkan pembahasan yang telah diuraikan, maka diambil kesimpulan sebagai berikut:

1. Pengaturan sanksi administrasi denda dalam Perda Nomor 8 Tahun 2013 tidak disertai dengan pengaturan tentang besaran denda yang dapat dibebankan terhadap pelanggarnya. Seharusnya dalam Perda terlebih dahulu mengatur jumlah denda maksimum yang dapat dijatuhkan terhadap pelanggar, baru ketentuan dan tatacara lebih lanjut diatur dengan Peraturan Walikota. Pengaturan besaran sanksi administrasi denda dalam Peraturan Walikota Nomor 84 Tahun 2018 tentang Tatacara Penerapan Sanksi Administrasi Peraturan Daerah Kota Jambi Nomor 8 Tahun 2013 tentang Pengelolaan Sampah, kurang tepat karena Pasal Pasal 56 ayat (2) yang mendelegasikan kewenangan pengaturan dengan Peraturan Walikota hanya mendelegasikan kewenangan pengaturan tentang tatacara pelaksanaan sanksi administrasi. Karena itu, sesuai dengan fungsinya sebagai peraturan pelaksana dari Perda, mestinya dalam Peraturan Walikota hanya memuat pengaturan sesuai yang didelegasikan. Selanjutnya, pengaturan besaran sanksi denda yang dituangkan dalam Keputusan Kepala Dinas Lingkungan Hidup ini juga tidak tepat dari segi penormaannya. Karena dari aspek norma hukum, keputusan merupakan beschikking yang sifatnya individual atau hanya ditujukan bagi orang tertentu saja, sementara Keputusan Kepala Dinas tersebut ditujukan bagi semua pelanggar. Seharusnya ketentuan tentang pelaksanaan Perda dituangkan dalam bentuk Peraturan Walikota.

2. Peran DLH Kota Jambi dalam penerapan sanksi administrasi denda terhadap pelanggaran atas larangan pembuangan sampah berdasarkan Perda Nomor 8 Tahun 2013, telah dilaksanakan mulai Tahun 2019 dengan ditetapkannya Peraturan Walikota Nomor 84 Tahun 2018. Namun dalam pelaksanaannya, berdasarkan tolok ukur yang digunakan terlihat bahwa peran DLH Kota Jambi dalam penerapan sanksi administrasi denda tersebut dapat dikatakan belum optimal. Dilihat dari kemampuan menerapkan besaran denda sesuai pedoman yang telah ditetapkan sebelumnya, terlihat bahwa belum semua pelanggar dikenakan besaran denda sesuai yang ditentukan dalam pedoman yang telah ditetapkan sebelumnya. Kemudian dilihat dari jumlah dan rentang waktu penerapan sanksi administrasi denda yang telah dilakukan dari Tahun 2019 sampai dengan Bulan Juni 2020 baru sebanyak 10 kali. Dalam hal ini dikatakan tidak sebanding dengan intensitas pelanggaran yang terlihat setiap hari, sedangkan penerapan sanksi administrasi denda yang dilakukan belum terlihat minimal satu kali setiap bulannya. Begitu pula dilihat dari jenis tindakan pelanggaran yang dikenakan sanksi administrasi denda, belum terlihat adanya penerapan sanksi administrasi terhadap semua jenis pelanggaran yang terjadi di lapangan, seperti belum adanya penerapan sanksi yang dijatuhkan terhadap pelanggaran larangan mengorek atau mengais sampah di TPS yang terjadi setiap hari, serta belum adanya penerapan sanksi administrasi denda terhadap tindakan pelanggaran larangan impor sampah. Berdasarkan ketiga hal tersebut, besarnya jumlah denda yang telah ditetapkan perlu ditinjau ulang dengan mempertimbangkan kemungkinan pelaksanaannya sehingga berbagai pelanggaran yang terjadi dapat dikenakan sanksi untuk menegakkan ketentuan larangan yang telah ditetapkan.

\section{DAFTAR PUSTAKA}

Daryanto, Kamus Lengkap Bahasa Indonesia, Surabaya: Apollo, 1998

Fajar ND Mukti dan Ahmad Yulianto, Dualisme Penelitian Hukum Normatif \& Empiris, Jakarta: Pustaka Pelajar, 2019

Ishaq, Metode Penelitian Hukum, Bandung: Alfabeta, 2017

Ilmar Aminuddin, Hukum Tata Pemerintahan, Jakarta: Prenamedia Group, 2014 
Herma Yanti et al, Peran Dinas Lingkungan Hidup Kota Jambi dalam Penerapan Sanksi Administrasi Denda Berdasarkan Peraturan Daerah Nomor 8 Tahun 2013 Tentang Pengelolaan Sampah

M. Hadjon Philipus dkk, Pengantar Hukum Administrasi Indonesia Introduction to the Indonesian Administrative Law, Yogyakarta: Gajah Mada University Press, 2001.

HR Ridwan, Hukum Administrasi Negara, Jakarta: PT. Raja Grafindo Persada, 2010

Suratman dan Philips Dillah, Metode Penelitian Hukum, Malang: Alfabeta,2014

\section{Peraturan Perundang-undangan}

Peraturan Daerah Kota Jambi Nomor 8 Tahun 2013 tentang Pengelolaan Sampah

Peraturan Daerah Kota Jambi Nomor 14 Tahun 2016 tentang Pembentukan dan Susunan Perangkat Daerah

Peraturan Walikota Jambi Nomor 84 Tahun 2018 tentang Tatacara Penerapan Sanksi Administrasi PerdaNomor 8 Tahun 2013 tentang Pengelolaan Sampah.

\section{Jurnal}

M. Muslih, Efektifitas PerdaKota Jambi No.8 Tahun 2013 tentang Pengelolaan Sampah Dalam Mewujudkan Lingkungan Sehat dan Bersih Di Kota Jambi, Jurnal Legalita, Vol.8 no. 2, (Desember 2016) : 44

Herma Yanti \& Chinthia Andari, Peranan Badan Pengelola Pajak dan Retribusi Daerah Dalam Mengoptimalkan Penerimaan Pajak Bumi dan Bangunan di Kabupaten Muaro Jambi, Jurnal Ilmiah Universitas Batanghari Jambi, Vol.17 no.3 (Oktober 2017) : 86 